\title{
PELATIHAN PRODUKSI BAHAN BANGUNAN UNTUK MENINGKATKAN KETERAMPILAN MASYARAKAT DI PROVINSI BANTEN
}

\author{
Fitri Aida Sari ${ }^{1}$, Telly Rosdiyani ${ }^{2}$ \\ ${ }^{1,2}$ Teknik Sipil, Universitas Banten Jaya, Jl. Syech Nawawi Albantani Serang Banten \\ Email: fitriaidasari@unbaja.ac.id
}

\begin{abstract}
Banten Province has large natural resources, especially natural resources in the form of wood. The amount of natural resources must be accompanied by human resources who can process natural resources so that they have a high selling value. KOTAKU, which operates under the Direktorat Jenderal Cipta Karya Kementerian Pekerjaan Umum dan Perumahan Rakyat in collaboration with the University of Banten Jaya, conducts training for the community to produce building materials, especially in the production of frames and doors. The objectives of the implementation of these activities include increasing the capacity of the community in producing building materials, especially the manufacture of frames and doors and as an effort to improve the economy of the people in Banten Province. This activity is carried out for four days by presenting instructors who have qualifications and experience in producing building materials. The target of this activity is the people living in the Banten Province, especially Lebak Regency, Serang City, and Serang Regency. After participating in this training activity, the community is expected to have better skills and abilities in processing wood and can create jobs, both for themselves and for others.
\end{abstract}

Keywords: Banten; Training; Wood; KOTAKU; PUPR.

\begin{abstract}
ABSTRAK
Provinsi Banten memiliki sumber daya alam besar terutama sumber daya alam yang berupa kayu. Besarnya sumber daya alam tersebut harus diiringi dengan sumber daya manusia yang dapat mengolah sumber daya alam agar memiliki nilai jual yang tinggi. KOTAKU yang begerak di bawah Direktorat Jenderal Cipta Karya Kementerian Pekerjaan Umum dan Perumahan Rakyat bekerjasama dengan Universitas Banten Jaya melakukan pelatihan kepada masyarakat untuk memproduksi bahan bangunan khususnya dalam produksi kusen dan daun pintu. Tujuan dari pelaksanaan kegiatan tersebut diantaranya meningkatkan kemampuan masyarakat dalam memproduksi bahan bangunan khususnya pembuatan kusen dan daun pintu serta sebagai upaya untuk meningkatkan perekonomian masyarakat di Provinsi Banten. Kegiatan ini dilaksanakan selama empat hari dengan menghadirkan instruktur-instruktur yang memiliki kualifikasi dan pengalaman dalam memproduksi bahan bangunan. Sasaran dari kegiatan ini adalah masyarakat yang berada di wilayah Provinsi Banten khususnya Kabupaten Lebak, Kota Serang, dan Kabupaten Serang. Setelah mengikuti kegiatan pelatihan ini masyarakat diharapkan memiliki keterampilan dan kemampuan yang lebih baik dalam mengolah kayu serta dapat menciptakan lapangan pekerjaan, baik untuk dirinya sendiri maupun orang lain.
\end{abstract}

Kata Kunci: Banten; Pelatihan; Kayu; KOTAKU; PUPR.

\section{PENDAHULUAN}

Provinsi Banten merupakan salah satu Provinsi yang terletak di pulau Jawa. Keberadaan Provinsi Banten yang dekat dengan ibukota negara membuat Provinsi ini memiliki peluang perkembangan perekonomian yang cukup besar. Namun semenjak pandemi covid-19 terjadi, 
banyak sektor perekonomian yang merugi dan gulung tikar. Berdasarkan keterangan yang disampaikan oleh Gubernur Banten bahwa pandemi covid-19 mengakibatkan 800 perusahaan tidak dapat bertahan dan akhirnya gulung tikar. Hal ini memberikan dampak pada peningkatan pengangguran di Provinsi Banten (Kompas, 2020). Untuk mengatasi permasalahan tersebut, pemerintah perlu memberikan dukungan kepada masyarakat guna menghidupkan perekonomian kembali. Langkah yang dapat dilakukan oleh pemerintah adalah memberikan dukungan kepada industri kecil rumah tangga. Salah satu industri rumah tangga yang dapat dikembangkan di Provinsi Banten yaitu industri di bidang produksi bahan bangunan dan bidang perkayuan. Menurut Hakim et al (2009) produksi kayu yang berasal dari Provinsi Banten meningkat dari tahun ke tahun. Besarnya kemampuan alam menghasilkan sumber daya kayu tersebut perlu didukung oleh sumber daya manusia yang baik berupa keterampilan pengolahan kayu menjadi barang-barang berdaya jual tinggi serta pengetahuan tentang material, desain serta cara pembuatannya (Taunaumang \& Sompotan, 2020).

Oleh karena itu, dibutuhkan pelatihan dan pendampingan masyarakat yang akan mendorong peningkatan kemampuan masyarakat untuk dapat mengolah kayu. Taunaumang (2019) berpendapat bahwa pemberian latihan kerja merupakan salah satu solusi yang tepat dalam meningkatkan pengetahuan dan keterampilan bagi masyarakat (tukang bangunan) sehingga mereka dapat bersaing dan memperoleh pekerjaan untuk meningkatkan pendapatan keluarga. Dalam hal ini, salah satu Direktorat yang memiliki program dalam melatih masyarakat agar memiliki kemampuan yang memadai adalah Direktorat Jenderal Cipta Karya Kementerian Pekerjaan Umum dan Perumahan Rakyat melalui program KOTAKU. KOTAKU merupakan singkatan dari Kota Tanpa Kumuh yang merupakan salah satu dari upaya yang dilakukan oleh Direktorat Jenderal Cipta Karya Kementerian Pekerjaan Umum dan Perumahan Rakyat untuk menangani dan memperkecil jumlah pemukiman kumuh di Indonesia (Kotaku, 2021). KOTAKU dapat melakukan Kerjasama dengan instansi yang bergerak di bidang pendidikan untuk melakukan pelatihan dan pendampingan yang dibutuhkan oleh masyarakat.

Salah satu program yang diadakan oleh KOTAKU dan berkolaborasi dengan instansi yang bergerak di bidang pendidikan adalah program pelatihan produksi bahan bangunan. Pada program tersebut, KOTAKU menggandeng Universitas Banten Jaya sebagai pelaksana sekaligus tuan rumah tempat kegiatan pelatihan dilaksanakan. Tujuan dari program tersebut diantaranya: (1) untuk mengurangi pengaguran yang terjadi di Provinsi Banten sebagai dampai dari pandemi covid-19; (2) meningkatkan kemampuan masyarakat dalam memproduksi bahan bangunan khususnya pembuatan kusen dan daun pintu; serta sebagai upaya dalam (3) meningkatkan perekonomian masyarakat di Provinsi Banten. Program dilaksanakan selama 
empat hari dengan menghadirkan berbagai pakar di bidang teknik sipil yang sudah banyak memiliki pengalaman di bidang konstruksi dan pembangunan.

\section{METODE}

Kegiatan diawali dengan persiapan yang dilakukan oleh panitia berupa: (1) rapat penentuan lokasi dan waktu pelaksanaan kegiatan; (2) pendataan peserta yang akan mengikuti kegiatan; (3) mempersiapkan bahan dan peralatan yang akan digunakan selama kegiatan; (4) menghubungi instruktur yang aka terlibat dalam pelaksanaan pelatihan; serta (5) menghubungi pihak-pihak terkait seperti perwakilan dari KOTAKU dan PUPR. Setelah persiapan selesai, selanjutnya dilaksanakanlah kegiatan pelatihan produksi bahan bangunan selama 4 hari pada tanggal 7 - 10 Desember 2020. Peserta produksi bahan yang terdaftar pada kegiatan ini sebanyak 26 orang yang berasal dari berbagai daerah di Provinsi Banten diantaranya berasal dari Serang dan Lebak Provinsi Banten.

Kegiatan dilaksanakan di Universitas Banten Jaya yang berlokasi di Jl. Syekh Moh. Nawawi Albantani Kp. Boru Kecamatan Curug, Banjarsari, Serang City, Banten. Peserta mendapatkan berbagai materi pelatihan baik berupa teori dan juga praktek. Pada hari pertama pelatihan, peserta mendapatkan pengetahuan mengenai pengantar pembuatan kusen, selanjutnya di hari kedua peserta mempraktekkan teori dan pengetahuan yang sudah didapatkan untuk mempraktekkannya di lapangan. Pada hari ketiga, peserta mendapatkan teori pengantar pembuatan daun pintu, dan di hari terakhir pelatihan peserta melakukan praktek pembuatan daun pintu. Kegiatan diakhiri dengan evaluasi dan pembuatan laporan yang dilakukan oleh pelaksana kegiatan.

\section{HASIL DAN PEMBAHASAN}

Kegiatan pelatihan produksi bahan dilaksanakan selama 4 hari pada tanggal $7-10$ Desember 2020. Sebelum memasuki area pelatihan, seluruh peserta diwajibkan untuk menjalani rapid tes untuk memastikan seluruh peserta bebas dari virus Covid-19. Setelah peserta pelatihan produksi bahan bangunan menjalani rapid tes dan dinyatakan non reaktif baik IGG maupun IGM nya, maka selanjutnya peserta pelatihan diarahkan untuk memasuki ruang pertemuan yang berada di Gedung Universitas Banten Jaya. Peserta diminta untuk melakukan registrasi dan mengisi lembar daftar kehadiran. Panitia memberikan perlengkapan kepada masing-masing peserta berupa APD Covid (masker, faceshield, handsanitizer, dan sabun), rompi, helm, sarung tangan, name tag serta ATK (block note dan pensil) yang semuanya dimasukkan ke dalam sebuah totebag berlogokan KOTAKU, PUPR serta Universitas Banten Jaya sebagai pelaksana. 

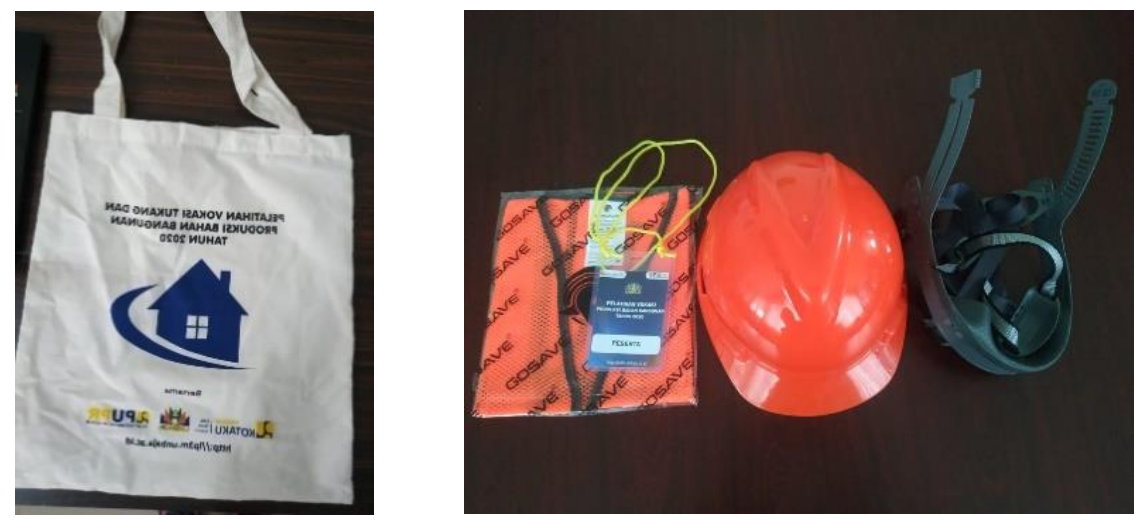

Gambar 1. Totebag Pelatihan Produksi Bahan

Acara diawali dengan pembukaan yang dihadiri oleh Perwakilan yang berasal dari Balai PPW Provinsi Banten, ketua pelaksana kegiatan pelatihan, serta Rektor UNBAJA. Ketiganya memberikan sambutan dan berharap kegiatan ini dapat berjalan dengan lancar serta menghasilkan masyarakat yang memiliki keterampilan guna menghasilkan bahan bangunan yang memiliki kualitas baik. Pada akhir acara pembukaan pelatihan produksi bahan, dilakukan penyerahan APD secara simbolis oleh perwakilan balai PPW Provinsi Banten.

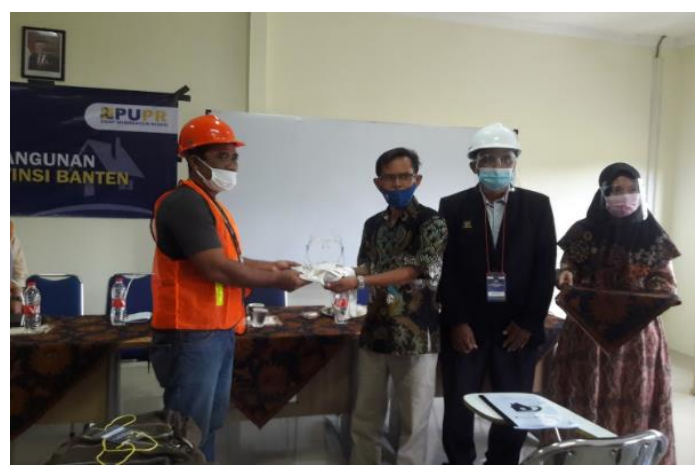

\section{Gambar 2. Penyerahan APD Pelatihan Produksi Bahan}

Sebelum beranjak ke acara selanjutnya, peserta dipersilahkan untuk melakukan istirahat (coffee break) selama beberapa menit. Peserta pelatihan diwajibkan mengerjakan soal pretest untuk menguji pemahaman awal yang dimiliki oleh peserta produksi bahan bangunan. Setelah pretest selesai dilaksanakan selanjutnya, materi pertama diawali dengan pemberian teori yang dilakukan di salah satu ruang (indoor) Universitas Banten Jaya. Materi yang disampaikan oleh bapak Bambang Hariyanto, S.T., M.T sebagai salah satu instruktur pada pelatihan produksi bahan. Materi yang disampaikan meliputi teori pekerjaan kusen. Pada hari pelatihan ke-2, hari 
pelatihan ke-3 dan hari pelatihan ke-4 dilakukan praktek yang didampingi oleh 2 orang instruktur beserta asisten instruktur. Pada hari ke-2 dilakukan praktek pembuatan kusen. Pada hari ke-3 dilakukan pemberian teori dan pengatar pembuatan daun pintu yang kemudian dilanjutkan dengan praktek pembuatan daun pintu. Pada hari ke-4 atau hari terakhir dilakukan lanjutan praktek pembuatan daun pintu.

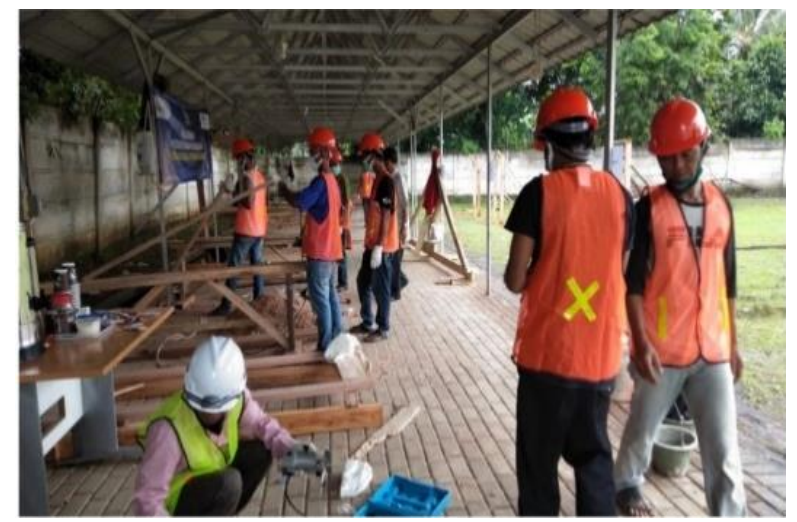

Gambar 3. Praktek Pelatihan Produksi Bahan

Selama kegiatan pelatihan produksi bahan berlangsung, untuk memantau perkembangan kegiatan serta hambatan yang terjadi, setiap harinya di akhir acara dilakukan evaluasi pelaksanaan kegiatan yang dilakukan bersama-sama oleh seluruh panitia pelatihan dan perwakilan dari OC KOTAKU. Adapun yang menjadi pembahasan evaluasi adalah sebagai berikut:

\section{Kehadiran Peserta}

Berdasarkan hasil rekapitulasi, monitoring dan evaluasi yang telah dilakukan, jumlah peserta yang hadir setiap harinya pada kegiatan pelatihan dipaparkan pada tabel di bawah ini.

Materi

Tabel 1. Kehadiran Peserta pada Kegiatan Pelatihan

\begin{tabular}{|c|c|c|c|c|c|c|}
\hline NO & $\begin{array}{c}\text { KOTA/ } \\
\text { KABUPATEN }\end{array}$ & NAMA & $\begin{array}{c}\text { HARI } \\
\text { KE-1 }\end{array}$ & $\begin{array}{c}\text { HARI } \\
\text { KE-2 }\end{array}$ & $\begin{array}{c}\text { HARI } \\
\text { KE-3 }\end{array}$ & $\begin{array}{l}\text { HARI } \\
\text { KE-4 }\end{array}$ \\
\hline 1 & \multirow{10}{*}{$\begin{array}{l}\text { KABUPATEN } \\
\text { LEBAK }\end{array}$} & Mahpudin & $\mathrm{x}$ & $\checkmark$ & $\checkmark$ & $\checkmark$ \\
\hline 2 & & Didih Sayuti & $\checkmark$ & $\checkmark$ & $\checkmark$ & $\sqrt{ }$ \\
\hline 3 & & Sapa'at & $\checkmark$ & $\checkmark$ & $\checkmark$ & $\checkmark$ \\
\hline 4 & & Chandra & $\checkmark$ & $\checkmark$ & $\checkmark$ & $\checkmark$ \\
\hline 5 & & Andri & $\checkmark$ & $\checkmark$ & $\checkmark$ & $\checkmark$ \\
\hline 6 & & Rusadi & $\checkmark$ & $\sqrt{ }$ & $\checkmark$ & $\checkmark$ \\
\hline 7 & & Johari & $\checkmark$ & $\checkmark$ & $\checkmark$ & $\checkmark$ \\
\hline 8 & & Suryani & $\checkmark$ & $\checkmark$ & $\checkmark$ & $\sqrt{ }$ \\
\hline 9 & & Ahmad Topan & $\sqrt{ }$ & $\sqrt{ }$ & $\sqrt{ }$ & $\sqrt{ }$ \\
\hline 10 & & Nasar & $\checkmark$ & $\sqrt{ }$ & $\checkmark$ & $\checkmark$ \\
\hline
\end{tabular}




\begin{tabular}{|c|c|c|c|c|c|c|}
\hline 11 & & Wahyudin & $\checkmark$ & $\checkmark$ & $\sqrt{ }$ & $\checkmark$ \\
\hline 12 & & Ahidin & $\checkmark$ & $\checkmark$ & $\checkmark$ & $\checkmark$ \\
\hline 13 & & A. Somad & $\checkmark$ & $\checkmark$ & $\mathrm{x}$ & $\checkmark$ \\
\hline 14 & & Ahmad Rohim & $\checkmark$ & $\checkmark$ & $\checkmark$ & $\checkmark$ \\
\hline 15 & & Nurdin & $\checkmark$ & $\checkmark$ & $\checkmark$ & $\checkmark$ \\
\hline 16 & & Edi & $\checkmark$ & $\checkmark$ & $\mathrm{x}$ & $\checkmark$ \\
\hline 17 & & Patah & $\sqrt{ }$ & $\checkmark$ & $\sqrt{ }$ & $\sqrt{ }$ \\
\hline 18 & & Dimyati & $\checkmark$ & $\checkmark$ & $\checkmark$ & $\checkmark$ \\
\hline 19 & & Ali & $\checkmark$ & $\checkmark$ & $\checkmark$ & $\checkmark$ \\
\hline 20 & & Sonhadi & $\sqrt{ }$ & $\checkmark$ & $\sqrt{ }$ & $\sqrt{ }$ \\
\hline 21 & & Cipto Suprianto & $\checkmark$ & $\checkmark$ & $\checkmark$ & $\checkmark$ \\
\hline 22 & & Ahmad Mahruf & $\checkmark$ & $\checkmark$ & $\checkmark$ & $\checkmark$ \\
\hline 23 & & Wahyudi & $\sqrt{ }$ & $\sqrt{ }$ & $\sqrt{ }$ & $\sqrt{ }$ \\
\hline 24 & & Herdi & $\checkmark$ & $\checkmark$ & $\checkmark$ & $\checkmark$ \\
\hline 25 & & Maman & $\checkmark$ & $\checkmark$ & $\checkmark$ & $\mathrm{x}$ \\
\hline 26 & KOTA SERANG & Karnadi & $\checkmark$ & $\sqrt{ }$ & $\sqrt{ }$ & $\sqrt{ }$ \\
\hline
\end{tabular}

Dari 32 orang peserta, selama 4 hari pelatihan, 6 orang peserta tidak hadir semenjak pelatihan hari pertama sampai hari terakhir. Sehingga secara keseluruhan, 7 orang peserta tidak hadir pada hari pelatihan ke-1, 8 orang peserta tidak hadir pada hari pelatihan ke-3, dan 7 orang peserta tidak hadir pada hari pelatihan ke-4. Persentase kehadiran peserta dari hari pertama sampai hari terakhir mencapai $82,81 \%$. Kehadiran peserta setiap harinya pada kegiatan pelatihan dapat juga dilihat pada grafik berikut ini:

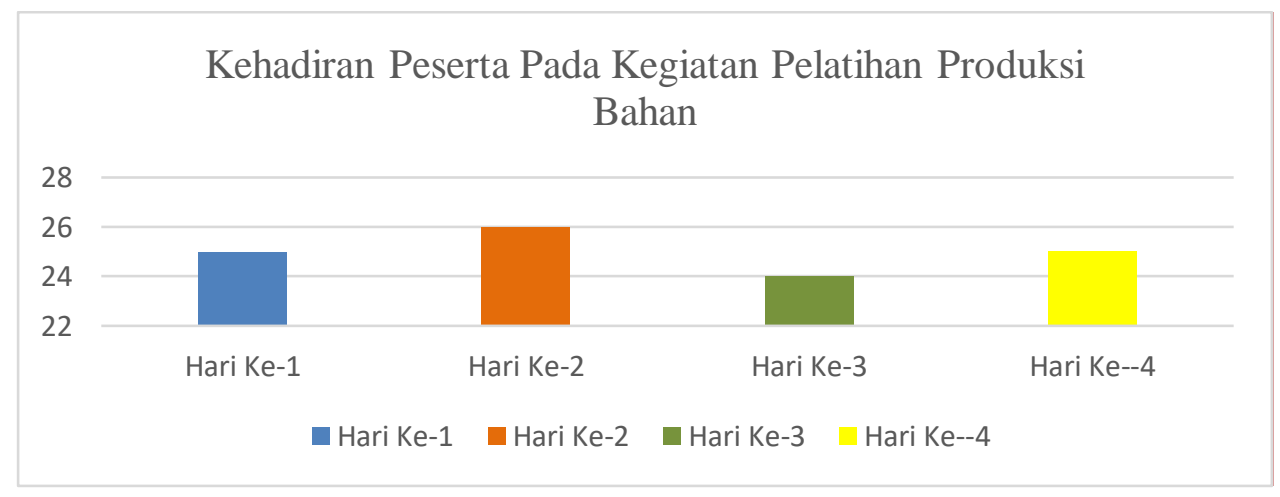

\section{Diagram 1. Kehadiran Peserta Pelatihan}

Sebelum diberikan materi, peserta kegiatan vokasi produksi bahan melakukan pretest untuk mengukur kemampuan awal peserta. Setiap peserta diberikan 10 soal pilihan ganda, hasil dari pretest yang dilakukan adalah sebagai berikut: 
Tabel 2. Hasil Pre Test Pelatihan Produksi Bahan

\begin{tabular}{|c|c|c|c|}
\hline NO & $\begin{array}{c}\text { KOTA/ } \\
\text { KABUPATEN }\end{array}$ & NAMA & NILAI PRETEST \\
\hline 1 & \multirow[t]{25}{*}{ KABUPATEN LEBAK } & Mahpudin & 50 \\
\hline 2 & & Didih Sayuti & 50 \\
\hline 3 & & Sapa'at & 40 \\
\hline 4 & & Chandra & 40 \\
\hline 5 & & Andri & 50 \\
\hline 6 & & Rusadi & 60 \\
\hline 7 & & Johari & 50 \\
\hline 8 & & Suryani & 40 \\
\hline 9 & & Ahmad Topan & 40 \\
\hline 10 & & Nasar & 60 \\
\hline 11 & & Wahyudin & 50 \\
\hline 12 & & Ahidin & 60 \\
\hline 13 & & A. Somad & 50 \\
\hline 14 & & Ahmad Rohim & 50 \\
\hline 15 & & Nurdin & 50 \\
\hline 16 & & Edi & 40 \\
\hline 17 & & Patah & 40 \\
\hline 18 & & Dimyati & 40 \\
\hline 19 & & Ali & 60 \\
\hline 20 & & Sonhadi & 40 \\
\hline 21 & & Cipto Suprianto & 50 \\
\hline 22 & & Ahmad Mahruf & 50 \\
\hline 23 & & Wahyudi & 40 \\
\hline 24 & & Herdi & 50 \\
\hline 25 & & Maman & 40 \\
\hline 26 & KOTA SERANG & Karnadi & 40 \\
\hline
\end{tabular}

Berdasarkan data hasil pretest tersebut dapat kita lihat bahwa pengetahuan awal yang dimiliki oleh tukang bangunan masih rendah, hal ini sejalan dengan pendapat yang disampaikan oleh (Bakhtiar et al (2019) bahwa banyak tukang bangunan yang belum memiliki keterampilan dan pengetahuan yang seharusnya mereka miliki terutama tentang bagaimana cara pengaplikasian pengetahuan yang mereka miliki. Untuk mengukur apakah pelatihan yang diberikan efektif atau tidak maka setelah peserta mendapatkan pelatihan produksi bahan bangunan yang berupa teori maupun praktek, peserta diberikan tes kembali (posttest) untuk mengukur kemampuan masing-masing peserta, apakah terjadi peningkatan kompetensi masyarakat (tukang bangunan) setelah diberikan pelatihan. Hasil posttest yang dilaksanakan adalah sebagai berikut: 
Tabel 3. Hasil Post Test dan Peningkatan Pelatihan Produksi Bahan

\begin{tabular}{|c|c|c|c|c|c|}
\hline NO & $\begin{array}{c}\text { KOTA/ } \\
\text { KABUPATEN }\end{array}$ & NAMA & $\begin{array}{c}\text { NILAI } \\
\text { PRETEST }\end{array}$ & $\begin{array}{c}\text { NILAI } \\
\text { POSTTEST }\end{array}$ & PENINGKATAN \\
\hline 1 & \multirow{25}{*}{$\begin{array}{l}\text { KABUPATEN } \\
\text { LEBAK }\end{array}$} & Mahpudin & 50 & 80 & 30 \\
\hline 2 & & Didih Sayuti & 50 & 80 & 30 \\
\hline 3 & & Sapa'at & 40 & 90 & 50 \\
\hline 4 & & Chandra & 40 & 80 & 40 \\
\hline 5 & & Andri & 50 & 90 & 40 \\
\hline 6 & & Rusadi & 60 & 90 & 30 \\
\hline 7 & & Johari & 50 & 80 & 30 \\
\hline 8 & & Suryani & 40 & 70 & 30 \\
\hline 9 & & Ahmad Topan & 40 & 70 & 30 \\
\hline 10 & & Nasar & 60 & 90 & 30 \\
\hline 11 & & Wahyudin & 50 & 80 & 30 \\
\hline 12 & & Ahidin & 60 & 100 & 40 \\
\hline 13 & & A. Somad & 50 & 80 & 30 \\
\hline 14 & & Ahmad Rohim & 50 & 80 & 30 \\
\hline 15 & & Nurdin & 50 & 90 & 40 \\
\hline 16 & & Edi & 40 & 80 & 40 \\
\hline 17 & & Patah & 40 & 80 & 40 \\
\hline 18 & & Dimyati & 40 & 80 & 40 \\
\hline 19 & & Ali & 60 & 90 & 30 \\
\hline 20 & & Sonhadi & 40 & 90 & 50 \\
\hline 21 & & Cipto Suprianto & 50 & 90 & 40 \\
\hline 22 & & Ahmad Mahruf & 50 & 90 & 40 \\
\hline 23 & & Wahyudi & 40 & 80 & 40 \\
\hline 24 & & Herdi & 50 & 100 & 50 \\
\hline 25 & & Maman & 40 & - & - \\
\hline 26 & $\begin{array}{c}\text { KOTA } \\
\text { SERANG }\end{array}$ & Karnadi & 40 & 80 & 40 \\
\hline
\end{tabular}

Berdasarkan hasil perbandingan antara hasil pretest dan posttest yang dilakukan terdapat peningkatan hasil dari masing-masing peserta dimana hal ini berarti bahwa pelatihan yang dilakukan memberikan kontribusi terhadap pengetahuan dan pemahaman yang harus dimiliki agar menjadi tukang yang handal dan terampil yang dapat memproduksi bahan bangunan sendiri. Pada akhir kegiatan, setiap peserta juga diberikan angket yang berisi evaluasi materi yang disampaikan oleh instruktur yang bertujuan untuk menganalisis apakah materi telah disampaikan dengan baik dan dipahami oleh setiap perserta. Terdapat dua materi yang di evaluasi diantaranya pembuatan kusen dan pembuatan daun pintu Hasil evaluasi terhadap masing-masing materi pelatihan adalah sebagai berikut: 


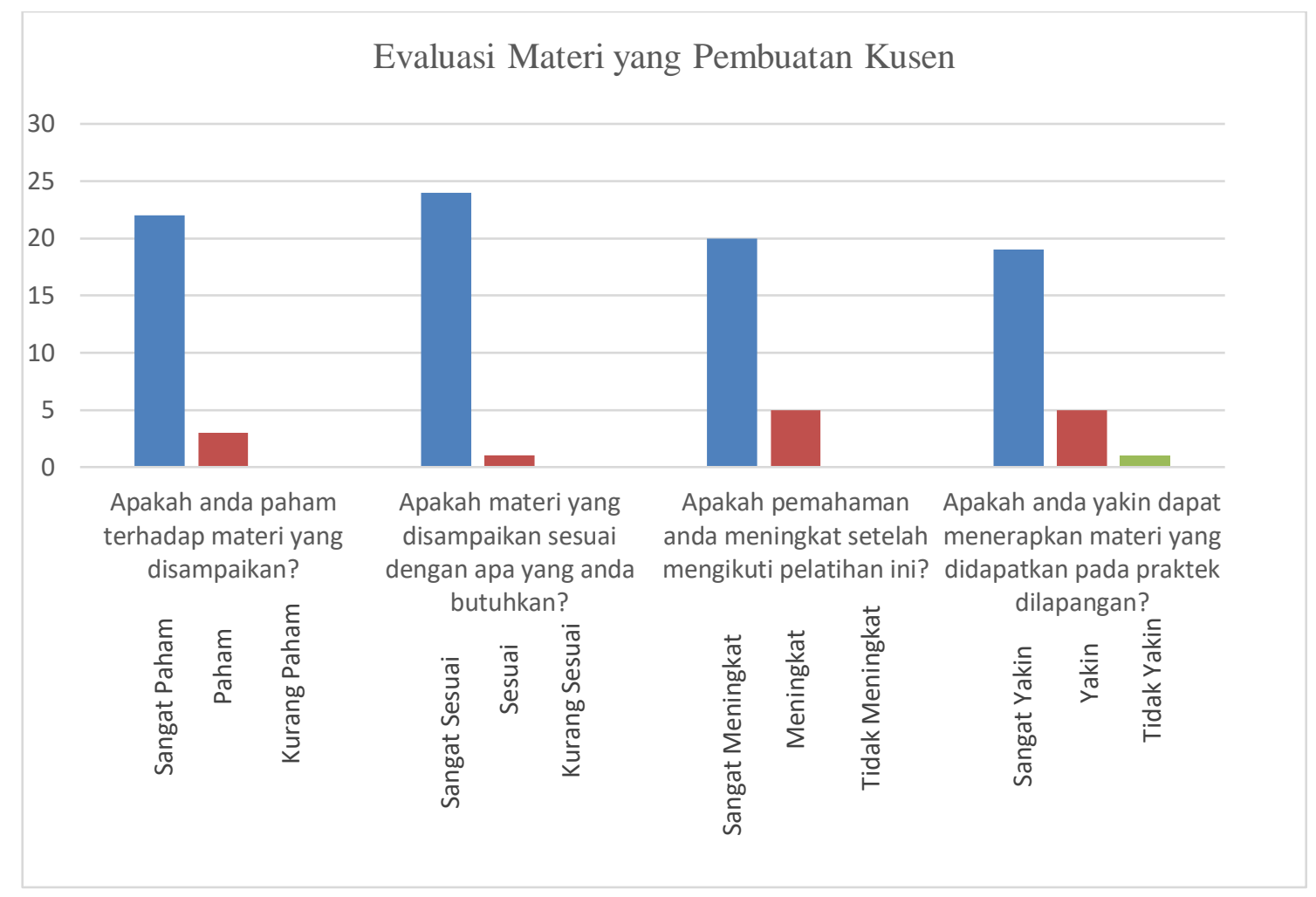

\section{Diagram 2. Evaluasi Materi Pembuatan Kusen}

Berdasarkan hasil angket evaluasi materi pembuatan kusen yang diberikan kepada peserta, dapat disimpulkan $88 \%$ peserta sangat paham akan materi yang disampaikan oleh instruktur, $12 \%$ peserta paham dan tidak ada peserta yang tidak paham. Selanjutnya peserta diberikan pertanyaan apakah materi yang disampaikan sesuai dengan apa yang mereka butuhkan, $96 \%$ peserta menjawab sangat sesuai, $4 \%$ peserta menjawab sesuai dan tidak ada peserta yang menyatakan kurang sesuai. Peserta juga diberikan pertanyaan terkait apakah mereka merasakan adanya peningkatan pemahaman terutama dalam hal pengetahuan mengenai produksi bahan bangunan setelah mengkuti pelatihan, $80 \%$ peserta menyatakan pemahaman mereka sangat meningkat, 20\% meningkat dan tidak ada peserta yang tidak merasakan peningkatan pada pemahaman yang meraka miliki setelah mengikuti pelatihan tersebut. Peserta juga diberikan pertanyaan terkait keyakinan meraka, apakah mereka memiliki keyakinan untuk dapat menerapkan segala ilmu yang sudah didapatkan pada pelatihan untuk dipraktekkan sendiri, $76 \%$ merasa sangat yakin, $20 \%$ yakin dan $4 \%$ merasa tidak yakin. Peserta yang merasa tidak yakin tersebut berharap agar ada kelanjutan dari kegiatan pelatihan ini sehingga ia dapat memperoleh pengetahuan dan keterampilan yang lebih banyak dan dalam lagi.

Selain melakukan evaluasi terhadap materi pembuatan kusen, peserta juga diberikan angket untuk mengevaluasi materi pembuatan daun pintu, hasil pengolahan anget tersebut adalah sebagai berikut: 


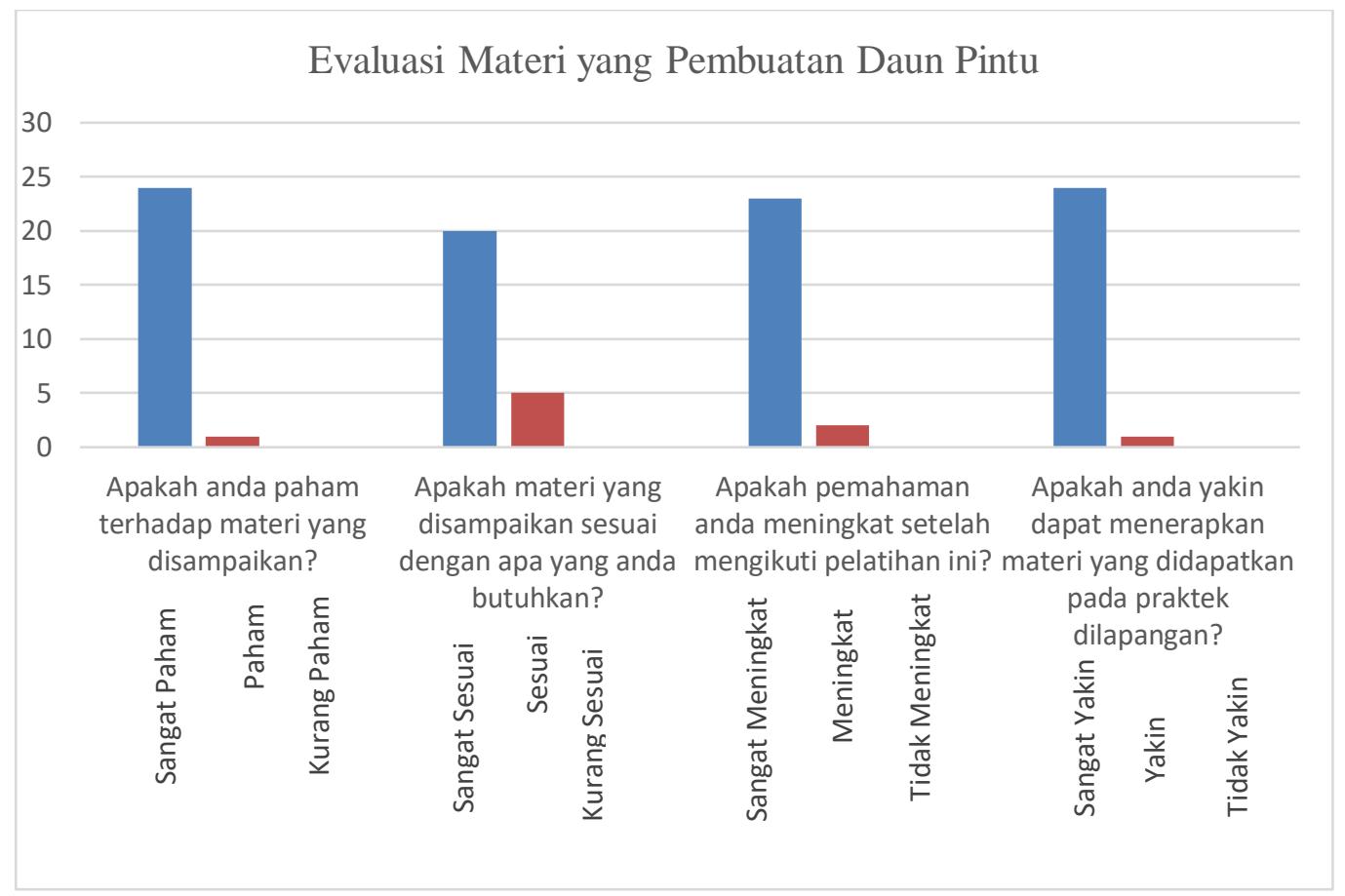

\section{Diagram 3. Evaluasi Materi Pembuatan Daun Pintu}

Berdasarkan hasil angket evaluasi materi pembuatan daun pintu yang dapat disimpulkan bahwa $96 \%$ peserta sangat paham akan materi yang disampaikan oleh instruktur, $4 \%$ peserta paham dan tidak ada peserta yang tidak paham. Selanjutnya peserta diberikan pertanyaan apakah materi yang disampaikan sesuai dengan apa yang mereka butuhkan, $80 \%$ peserta menjawab sangat sesuai, $20 \%$ peserta menjawab sesuai dan tidak ada peserta yang menyatakan kurang sesuai. Peserta juga diberikan pertanyaan terkait apakah mereka merasakan adanya peningkatan pemahaman terutama dalam hal pengetahuan mengenai produksi bahan bangunan setelah mengkuti pelatihan, $92 \%$ peserta menyatakan pemahaman mereka sangat meningkat, $8 \%$ meningkat dan tidak ada peserta yang tidak merasakan peningkatan pada pemahaman yang meraka miliki setelah mengikuti pelatihan tersebut. Peserta juga diberikan pertanyaan terkait keyakinan meraka, apakah mereka memiliki keyakinan untuk dapat menerapkan segala ilmu yang sudah didapatkan pada pelatihan untuk dipraktekkan sendiri, 96\% merasa sangat yakin, $4 \%$ yakin tidak ada peserta yang merasa tidak yakin.

\section{KESIMPULAN}

Pemerintah perlu untuk memfasilitasi masyarakatnya dalam memperoleh pengetahuan dan keterampilan yang lebih baik guna mendukung perekonomian masyarakat. Salah satu 
program yang dapat dilaksanakan untuk meningkatkan kemampuan masyarakat adalah pelatihan produksi bahan bangunan. Pelatihan produksi bahan bangunan ini merupakan kerjasama yang terjadi antara PUPR, KOTAKU serta Universitas Banten Jaya. Kegiatan dilaksanakan selama emapat hari yang memadukan antara pembelajaran yang berupa teori dan praktek secara langsung yang didampingi oleh instruktur berpengalaman. Melalui pelatihan yang dilaksanakan tersebut masyarakat merasakan manfaat berupa peningkatan pemahaman tentang bagaimana mengolah kayu menjadi kusen dan daun pintu yang siap untuk dijual. Masyarakat yang mengikuti pelatihan tersebut berharap program ini dapat dilaksanakan secara rutin dan berkelanjutan sehingga dapat membantu masyarakat untuk terus meningkatkan kemampuan dan keterampilan khsusnya di bidang produksi bahan bangunan.

\section{DAFTAR PUSTAKA}

Bakhtiar, et al. (2019). Pelatihan Cara Menghitung Anggaran Biaya Pelaksanaan ( RAP) Pada Bangunan Rumah Sederhana untuk Tukang Bangunan Gampong Mesjid Punteut Kecamatan Blang Mangat. 3(1), 180-184.

Hakim, I., Dwiprabowo, H., \& Effendi, R. (2009). Kajian Peredaran Kayu Rakyat di Wilayah Jawa Bagian Barat. Jurnal Penelitian Sosial Dan Ekonomi Kehutanan, 6(1), 15-37. https://doi.org/10.20886/jpsek.2009.6.1.15-37

Kompas. (2020). 800 Industri Di Banten Bangkrut Akibat Pandemi Covid-19. [Online]. Diakses dari https://regional.kompas.com/read/2020/11/27/06524021/800-industri-di-bantenbangkrut-akibat-pandemi-covid-19

Kotaku. (2021). Tentang Program Kota Tanpa Kumuh (KOTAKU). [Online]. Diakses dari http://kotaku.pu.go.id/page/6880/tentang-program-kota-tanpa-kumuh-kotaku.

Taunaumang, He, \& Sompotan, A. (2020). PPM Latihan Kerja bagi Masyarakat Tentang Disain dan Konstruksi Baja Ringan di Kota Manado. Abdimas: Jurnal Pengabdian Kepada Masyarakat, 13(1), 75-82. https://doi.org/10.36412/abdimas.v13i1.2147

Taunaumang, H. (2019). Peningkatan Pengetahuan dan Ketrampilan Masyarakat Tukang tentang Disain dan Konstrukasi Atap Seng Berbasis Baja Ringan. Edupreneur: Jurnal Pengabdian Kepada Masyarakat Bidang Kewirausahaan, 2(2), 37-44. https://doi.org/10.36412/edupreneur.v2i2.988 